\title{
PENGARUH PERTUMBUHAN EKONOMI DAN PENGANGGURAN TERHADAP INDEKS PEMBANGUNAN MANUSIA (IPM) DI PROVINSI SUMATERA SELATAN PERIODE TAHUN 2004-2018
}

\section{Novegya Ratih Primandari}

\begin{abstract}
This paper is aimed to analyze of how the economic growth and unemployment influence the Human Development Index (HDI) in South Sumatra Province in 2004 - 2018 period. The analytical tool used is multiple linear regression in which economic growth and unemployment as independent variables and the index of human development as the dependent variable. The data used are time series data from 2004 - 2018 sourced from BPS. Based on multiple linear regression analysis results show that growth and unemployment have a positive effect on the human development index both partially and simultaneously. As for the contribution of the effect of economic growth and unemployment on the human development index the results were $45.3 \%$ and the remaining $54.7 \%$ contribution came from other variables such as poverty, education level and health level.
\end{abstract}

Keywords: Economic Growth, Unemployment, Human Development Index

(C2019 Universitas Prof. Dr. Hazairin, SH.

\section{PENDAHULUAN}

Keberhasilan suatu pembangunan manusia tidak dapat dipisahkan dari adanya campur tangan pemerintah dalam menetapkan peraturan atau regulasi. Tercapainya tujuan pembangunan manusia yang dapat ditinjau dari Indeks Pembangunan Manusia (IPM). Peranan pemerintah dalam pembangunan manusia adalah melalui pengeluaran pemerintah sektor publik yang tercermin pada anggaran di bidang kesehatan yang fungsinya untuk meningkatkan angka harapan hidup maupun untuk menurunkan angka kematian. Sedangkan untuk anggaran dibidang pendidikan berfungsi untuk meningkatkan akses masyarakat pada pendidikan yang baik dan murah, dengan harapan angka melek huruf dapat meningkat.

Terdapat tiga indikator untuk mengukur IPM. Yang pertama adalah angka harapan hidup pada waktu lahir (life expectancy at birth) yaitu digunakan untuk mengukur tingkat kesehatan penduduk, yang kedua angka melek huruf penduduk dewasa (adult literacy rate) dan rata-rata lama sekolah (mean years of schooling) yaitu digunakan untuk mengetahui tingkat pendidikan, dan yang ketiga adalah kemampuan daya beli (purchasing powerparity) yang digunakan untuk mengukur standar hidup mayarakat. (Kuncoro, 2004).

Novegya Ratih Primandari( $₫)$

Universitas Baturaja

Email : novegya.iesp@gmail.com 
Pemerintah harus mampu menjaga kemampuan daya beli dari masyarakat yang hampir miskin khususnya di perkotaan, karena kelompok masyakat ini sangat rentan dan mudah jatuh ke bawah garis kemiskinan. Untuk daerah perdesaan perlu ditunjang dengan sarana dan prasana yang memadai sehingga tingkat kemiskinan di pedesaan dapat semakin ditekan. Besarnya jumlah angkatan kerja menuntut kesempatan atau lapangan kerja yang lebih banyak. Lapangan kerja datang dari pertumbuhan ekonomi. Namun pertumbuhan ekonomi tidak selalu menghasilkan lapangan kerja yang besar, sehingga akan selalu ada angkatan kerja yang tidak terserap oleh pasar. Bagian yang tidak terserap ini dikenal sebagai penganggur dan rasio penganggur terhadap total angkatan kerja disebut dengan istilah pengangguran.

Pengangguran merupakan indikator output ketenagakerjaan yang menggambarkan proporsi angkatan kerja yang menjadi penganggur atau tidak memiliki pekerjaan tapi aktif mencari pekerjaan/mempersiapkan suatu usaha, dengan demikian tingginya pengangguran mempunyai implikasi sosial yang luas karena pengangguran menjadi penyebab utama timbulnya kemiskinan dan meningkatkan potensi kerawanan sosial. Sementara dari sisi ekonomi, mereka yang menjadi penganggur tidak mempunyai pendapatan sehingga akan berkurang konsumsinya. Semakin tinggi pengangguran, semakin tidak efisien pula perekonomian wilayah tersebut.

Pemerintah Daerah di Indonesia sering kali menggunakan output tenaga kerja dalam menilai IPM di wilayahnya, begitu juga dengan Pemerintah Provinsi Sumatera Selatan. Pada tahun 2018 tingkat IPM Provinsi Sumatera Selatan sebesar 69,39\% yang berarti berada pada tahap menengah antara 50-79,9.

Berikut ini adalah data Indeks Pembangunan Manusia Kabupaten/Kota di Provinsi Sumatera Selatan tahun 2018.

Tabel 1. Indeks Pembangunan Manusia Provinsi Sumatera Selatan Tahun 2018

\begin{tabular}{|c|l|c|}
\hline No. & \multicolumn{1}{|c|}{ Kabupaten / Kota } & IPM \\
\hline 1. & Ogan Komering Ulu & 69,01 \\
\hline 2. & Ogan Komering Ulu Timur & 68,58 \\
\hline 3. & Ogan Komering Ulu Selatan & 64,84 \\
\hline 4. & Ogan Komering Ilir & 66,57 \\
\hline 5. & Ogan ilir & 66,43 \\
\hline 6. & Muara Enim & 68,28 \\
\hline 7. & Lahat & 66,99 \\
\hline 8. & Musi Rawas & 66,18 \\
\hline 9. & Musi Banyuasin & 67,57 \\
\hline 10 & Banyuasin & 66,4 \\
\hline 11. & Empat Lawang & 64,81 \\
\hline 12. & Penukal Abab Lematang Ilir & 63,49 \\
\hline 13. & Musi Rawas Utara & 63,75 \\
\hline 14. & Palembang & 77,89 \\
\hline 15. & Prabumulih & 74,04 \\
\hline 16. & Pagar Alam & 67,62 \\
\hline 17. & Lubuk Linggau & 74,09 \\
\hline & Sumatera Selatan & 69,39 \\
\hline
\end{tabular}

Sumber : BPS Provinsi Sumatera Selatan, 2018. 
Pada Tabel 1 dapat dijelaskan bahwa tingkat IPM dari 17 Kabupaten/Kota Provinsi Sumatera Selatan Tahun 2018 mempunyai rata-rata sebesar 69,39\%, Kota Palembang memiliki IPM yang tertinggi yaitu sebesar 77,89\% disusul oleh Kabupaten Lubuk Linggau dan Kota Prabumulih yang masing-masing sebesar 74,09\% dan 74,04\% sedangkan IPM terendah dimiliki oleh Kabupaten Penukal Abab Lematang Ilir sebesar 63,49\% disusul oleh Musi Rawas Utara dengan nilai IPM 63,75\%. Berdasarkan Tabel 1 tersebut dapat dilihat bahwa IPM Provinsi Sumatera Selatan belum memperlihatkan nilai yang optimal karena nilainya masih jauh dari angka 100. Artinya bahwa Penduduk di Provinsi sumatera selatan masih banyak yang belum mencapai sasaran dalam bidang kesehatan yaitu mencapai angka harapan hidup hingga 85 tahun, sebagian penduduk masih ada yang belum mengenyam pendidikan, dan tingkat pengeluaran dan konsumsi masyarakat masih ada yang belum mencapai standar hidup layak.

Provinsi Sumatera Selatan selama 5 tahun terakhir memiliki tingkat pertumbuhan ekonomi yang cukup baik, meningkat dari tahun ke tahun meskipun peningkatannya tidak terlalu besar, begitu pula dengan IPM dari tahun 2014 sampai dengan tahun 2018 mengalami peningkatan, seperti yang terlihat pada Tabel 2.

Tabel 2. Pertumbuhan Ekonomi, Pengangguran, dan IPM Provinsi Sumatera Selatan Tahun 2014-2018

\begin{tabular}{|c|c|c|c|c|}
\hline No & Tahun & $\begin{array}{c}\text { Pertumbuhan } \\
\text { Ekonomi (\%) }\end{array}$ & $\begin{array}{c}\text { Pengangguran } \\
\mathbf{( \% )}\end{array}$ & $\begin{array}{c}\text { IPM } \\
\mathbf{( \% )}\end{array}$ \\
\hline 1 & 2014 & 4,68 & 4,96 & 66,75 \\
\hline 2 & 2015 & 4,79 & 6,07 & 67,46 \\
\hline 3 & 2016 & 4,42 & 4,31 & 68,24 \\
\hline 4 & 2017 & 5,04 & 4,39 & 68,86 \\
\hline 5 & 2018 & 6,04 & 4,23 & 69,39 \\
\hline
\end{tabular}

Sumber : BPS Provinsi Sumatera Selatan, 2018.

Akan tetapi, tidak demikian dengan tingkat pengangguran, kondisi pengangguran di Provinsi Sumatera Selatan mengalami fluktuatif walaupun secara umum menurun namun di tahun 2015 mengalami peningkatan yang cukup tinggi sebesar 1,11\% dari tahun 2014. Hal ini menimbulkan pertanyaan besar yang seharusnya secara teori di saat tingkat pengangguran akan meningkat apabila IPM nya rendah begitu pula sebaliknya. Fenomena ini juga terjadi di Tahun 2017 dimana tingkat pengangguran meningkat sebesar $0,08 \%$ disaat IPM mengalami peningkatan $0,62 \%$ dari tahun sebelumnya.

\section{LANDASAN TEORI}

\section{Indeks Pembangunan Manusia (IPM)}

Indeks Pembangunan Manusia (IPM) terdapat tiga indikator komposit yang digunakan untuk mengukur pencapaian rata-rata suatu negara dalam pembangunan manusia, yaitu: lama hidup, yang diukur dengan angka harapan hidup ketika lahir; pendidikan yang diukur berdasarkan rata-rata lama bersekolah dan angka melek huruf penduduk usia 15 tahun ke atas; standar hidup yang diukur dengan pengeluaran perkapita yang telah disesuaikan menjadi paritas daya beli. Nilai indeks ini berkisar antara 0-100. Indeks Pembangunan Manusia (IPM) atau Human Development Indeks (HDI) merupakan salah satu pendekatan untuk mengukur tingkat keberhasilan 
pembangunan manusia. IPM digunakan untuk mengukur upaya pencapaian pembangunan manusia suatu negara. Walaupun tidak dapat mengukur semua dimensi dari pembangunan, namun mampu mengukur dimensi pokok pambangunan manusia yang dinilai mencerminkan status kemampuan dasar (basic capabilities) penduduk. IPM dihitung berdasarkan data yang dapat menggambarkan keempat komponen yaitu angka harapan hidup yang mewakili bidang kesehatan, angka melek huruf, dan rata-rata lamanya bersekolah mengukur capaian pembangunan di bidang pendidikan, dan kemampuan daya beli/paritas daya beli (PPP) masyarakat terhadap sejumlah kebutuhan pokok yang dilihat dari rata-rata besarnya pengeluaran perkapita sebagai pendekatan pendapatan yang mewakili capaian pembangunan untuk hidup layak. (UNDP, 1995).

Indeks Pembangunan Manusia (IPM) terdiri dari beberapa komponen (BPS, 2019), yaitu sebagai berikut:

1. Angka Harapan Hidup (AHH)

Angka harapan hidup identik dengan aspek kesehatan yang merupakan unsur penting yang berkaitan dengan kemampuan penduduk dalam hal seberapa lama harapan hidup dapat mencapai yang mengisyaratkan tingkat kesehatan. Angka harapan hidup juga sangat dipengaruhi oleh banyak kematian bayi dan balita yang memang masih sangat rentan hidupnya serta kematian ibu saat melahirkan. Kematian dapat dipengaruhi oleh tingkat kesehatan penduduk yang disebabkan oleh kurangnya asupan gizi, dan kebersihan lingkungan. Angka kematian bayi dan balita terjadi selain disebabkan oleh kurangnya asupan gizi juga disebabkan oleh keadaan lingkungan disekitar, seperti: sumber air bersih, fasilitas buang air besar serta jarak pembuangan tinja dari saluran air.

2. Angka Melek Huruf (AMH) dan Rata-rata Lama Sekolah

Tingkat melek huruf/buta huruf dan angka partisipasi sekolah merupakan indikator yang digunakan untuk mengukur tingkat pendidikan penduduk, selain seberapa lamanya waktu sekolah yang ditempuh.

Rata-rata lama sekolah penduduk 15 tahun ke atas yang berdasarkan pendidikannya, mewujudkan program wajib sembilan tahun, selain itu peningkatan program-program bagi mereka yang belum memiliki ijazah dengan mengupayakan program kejar paket dan sebagainya. Walaupun masih merupakan sebuah tantangan bagi dunia pendidikan khususnya pemerintah dan dinas terkait agar lebih meningkat kualitas pengetahuan penduduknya baik melalui pendidikan formal di sekolah maupun informal diluar sekolah seperti menggalakkan program-program Kejar Paket atau memperbanyak sekolah-sekolah terbuka di wilayah yang sulit dijangkau.

3. Daya Beli

Untuk menunjukkan tingkat kemampuan ekonomi penduduk di suatu wilayah dapat dilihat dari tingkat kemampuan daya beli masyarakat. Dalam mengukur tingkat perekonomian daerah dapat digunakan Produk Domestik Regional Bruto (PDRB). PDRB mencerminkan suatu proses kegiatan perekonomian di suatu wilayah yang dihitung dari seluruh pencapaian transaksi yang dilakukan oleh penduduk dari berbagai sektor, sehingga bapabila PDRB suatu daerah tinggi maka dapat disimpulkan bahwa makin tinggi pula tingkat perekonomian daerah tersebut. 


\section{Pertumbuhan Ekonomi}

Pertumbuhan ekonomi merupakan proses perubahan kondisi perekonomian yang dapat diukur dengan menggunakan Produk Domestik Bruto (PDB) maupun Produk Domestik Regional Bruto (PDRB) (Adisasmita, 2015).

Pertumbuhan ekonomi adalah suatu proses dari kenaikan output perkapita dalam jangka panjang. Pertumbuhan Ekonomi meliputi 3 (tiga) aspek, yaitu: pertama, pertumbuhan ekonomi merupakan suatu proses yang berkembang dari waktu ke waktu. Kedua, pertumbuhan ekonomi ada hubungannya dengan kenaikan output perkapita. Dan yang ketiga pertumbuhan ekonomi dapat dikatakan meningkat apabila dalam jangka panjang mengalami kenaikan pendapatan perkapita.(Budiono, 1999).

Terdapat 3 (tiga) komponen penting dalam pertumbuhan ekonomi yang berasal dari berbagai teori pertumbuhan yang ada yakni teori Harold Domar, Neoklasik, dari Solow, dan teori Endogen oleh Romer, antara lain:

1. Akumulasi modal, yang merupakan semua bentuk atau jenis investasi baik berupa tanah, peralatan, atau mesin maupun modal dalam bentuk sumber daya manusia.

2. Pertumbuhan penduduk, pertambahan penduduk akan memperbesar jumlah tenaga kerja.

3. Kemajuan teknologi, kemajuan perekonomian disuatu negara salah satunya dipengaruhi oleh kemajuan teknologi.

\section{Pengangguran}

Menurut Badan Pusat Statistik (BPS) dalam indikator ketenagakerjaan, pengangguran merupakan penduduk yang tidak bekerja tetapi sedang mencari pekerjaan atau sedang mempersiapkan suatu usaha baru atau penduduk yang tidak mencari pekerjaan karena sudah diterima bekerja tetapi belum mulai bekerja.

Pengangguran merupakan permasalahan makroekonomi yang memiliki pengaruh besar dan secara langsung bagi. Secara umum, kehilangan pekerjaan dapat mengakibatkan penurunan tingkat kesejateraan dan menjadi tekanan secara psikologis. Sehingga tidak mengherankan bila pengangguran menjadi bahan perbincangan yang cukup menarik dalam perdebatan politik dan para politisi sering mengklaim bahwa kebijakan yang mereka tawarkan akan membantu menciptakan lapangan kerja (Mankiw, 2003).

Dampak negarif dari pengangguran adalah dapat mengurangi pendapatan masyarakat yang itu berarti tingkat kemakmuran dan kesejahteraan masyarakat akan menurun. Tingkat kesejahteran masyarakat yang menurun akibat dari pengangguran dapat mempengaruhi indeks pembangunan manusia karena dengan tidak memiliki pendapatan maka penduduk tidak dapat memenuhi kebutuhan-kebutuhannya termasuk pendidikan, kesehatan dan sudah tentu akan menurunkan daya beli. Dalam bidang politik pengangguran memberikan efek buruk karena kemungkinan akan terjadi kekacauan politik dan sosial yang berpengaruh pada tingkat kesejahteraan masyarakat. (Sukirno, 2013).

\section{METODOLOGI}

Penelitian ini dilakukan di Provinsi Sumatera Selatan. Penelitian ini menganalisis pengaruh pertumbuhan ekonomi dan pengangguran terhadap indeks pembangunan manusia di Provinsi Sumatera Selatan tahun 2004-2018. Data yang digunakan adalah data sekunder yang diperoleh dari BPS. 


\section{Metode Analisis}

\section{Asumsi Klasik}

Asumsi klasik adalah analisis yang digunakan untuk menilai apakah didalam analisis regresi linear berganda terdapat permasalahan-permasalahan asumsi klasik, yang terdiri dari beberapa hal :

1. Uji Normalitas

Uji normalitas dapat dilakukan dengan uji normal P Plot.

2. Uji Multikolinearitas

Uji multikolinearitas dilakukan untuk melihat apakah ada korelasi antara variabel bebas dengan memperhatikan nilai tolerance dan VIF.

a) Jika nilai Tolerance $<0,10$ dan nilai VIF $>10$ artinya terdapat gangguan multikolinearitas.

b) Jika nilai Tolerance $>0,10$ dan nilai VIF $<10$ artinya terbebas dari gangguan multikolinearitas.

3. Uji Heteroskedastisitas

Dalam Penelitian ini menggunakan scatter plot untuk mengetahui ada tidaknya penyimpangan heteroskedastisitas.

4. Uji Autokorelasi

Untuk memeriksa ada atau tidaknya autokorelasi, dalam penelitian ini menggunakan Uji Durbin Watson.

\section{Analisis Regresi linear Berganda}

Persamaan regresi linear berganda adalah :

$$
Y=u+\beta_{1} X_{1}+\beta_{2} X_{2}+\varepsilon
$$

$u \quad=$ nilai konstata

$\beta_{1}, \beta_{2} \quad=$ nilai koefisien regresi

$X_{1} \quad=$ Pertumbuhan Ekonomi

$X_{2} \quad=$ Pengangguran

$Y \quad=$ Indeks Pembangunan Manusia (IPM)

$\varepsilon \quad=$ Error term

\section{Pengujian Hipotesis}

1. Uji t (uji secara individual)

Untuk menunjukkan seberapa besar pengaruh variabel independen secara individual terhadap variabel dependen. jika nilai sig $<0,05$ artinya berpengaruh tidak signifikan.

2. Uji F (secara serentak)

Untuk menunjukan seberapa besar pengaruh variabel independen terhadap variabel dependen secara serentak. Jika jika nilai sig $<0,05$ artinya berpengaruh tidak signifikan.

\section{A. Analisis Koefisien Determinasi $\left(\mathbf{R}^{2}\right)$}

Koefisien Determinasi $\left(\mathrm{R}^{2}\right)$ digunakan untuk menyatakan besar kecilnya sumbangan variabel $\mathrm{X}$ terhadap $\mathrm{Y}$. 


\section{HASIL DAN PEMBAHASAN}

\section{Uji Asumsi Klasik}

1. Uji Normalitas

Berdasarkan Gambar 1. P-Plot dapat disimpulkan bahwa semua titik-titik berada disekitar garis diagonal sehingga dapat dikatakan berdistribusi normal.

\section{Gambar 1. P-Plot}

\section{Normal P.P Plot of Regression Standardized Residual}

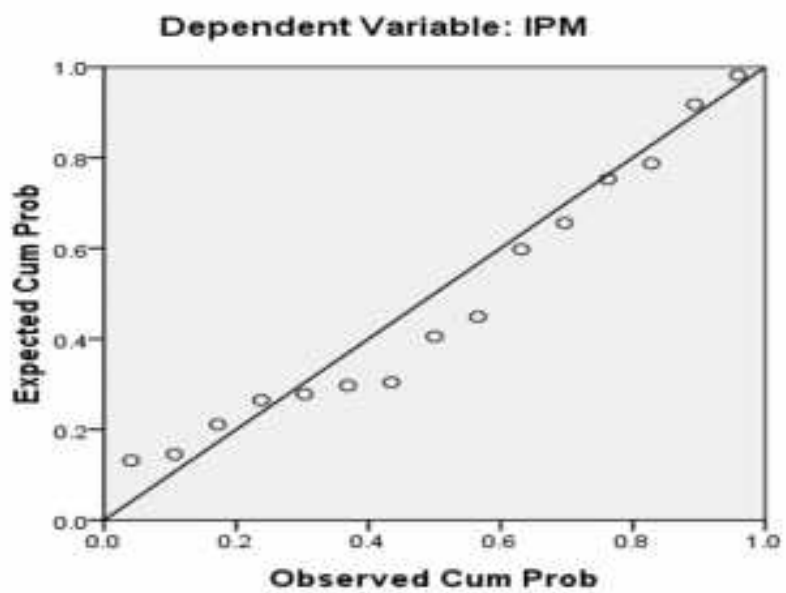

a) Uji Multikolinieritas

Berdasarkan tabel 4. Nilai tolerance sebesar 0,934 lebih dari 0,10 dan VIF 1,017 lebih kecil dari 10 sehingga dapat disimpulkan tidak ada korelasi antara variabel bebas dan terbebas dari gangguan multikolinearitas.

b) Uji Heteroskedastisitas

Uji heteroskedastisitas dapat dilihat dari gambar scatter plot yang titiktitiknya menyebar yang artinya tidak terjadi heteroskedastisitas.

\section{Gambar 2. Scatter Plot}

Scatterplot

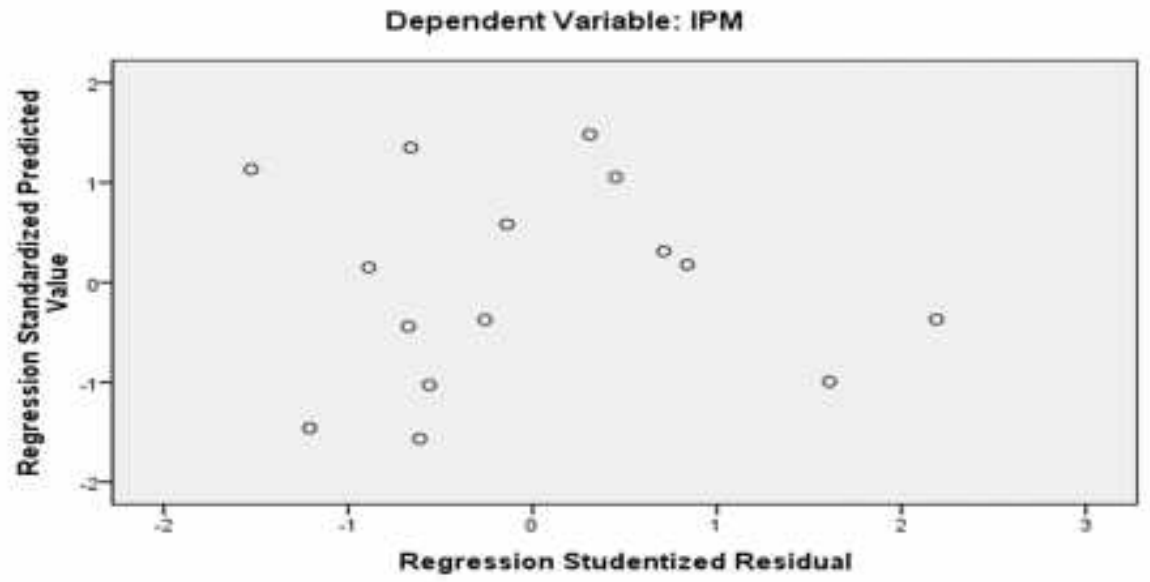


c) Uji Autokorelasi

Berdasarkan Tabel 3 nilai Durbin-Watson dapat diketahui bahwa nilai DW sebesar 1,540 sehingga dapat disimpulkan bahwa tidak terjadi gangguan autokorelasi karena DW berada diantara -2 sampai +2 .

Tabel 3. Nilai Durbin-Watson

\begin{tabular}{|l|c|}
\hline Model & Durbin-Watson \\
\hline 1 & 1,540 \\
\hline
\end{tabular}

Sumber: Data Diolah, 2019.

\section{Analisis Regresi Linier Berganda}

Berdasarkan analisis linier berganda diperoleh persamaan sebagai berikut:

$$
\mathrm{Y}=59,052+1,657 \mathrm{X}_{1}+0,389 \mathrm{X}_{2}
$$

Persamaan diatas dapat diintepretasikan bahwa nilai konstanta sebesar 59,052 mengandung makna bahwa jika tidak ada pertumbuhan ekonomi dan pengangguran atau kedua variabel tersebut bernilai nol maka IPM sebesar 59,052\%. Nilai koefisien $X_{1}$ sebesar 1,657 bernilai positif artinya jika pertumbuhan ekonomi meningkat sebesar $1 \%$ maka IPM juga akan meningkat sebesar 1,5657\% dengan asumsi variabel pengangguran tidak berubah. Nilai koefisien $\mathrm{X}_{2}$ sebesar 0,389 bernilai positif artinya jika pengangguran meningkat $1 \%$ maka IPM juga akan meningkat sebesar $0,389 \%$ dengan asumsi variabel pertumbuhan ekonomi tetap.

Tabel 4. Koefisien Regresi Linier Berganda

\begin{tabular}{|l|c|c|c|}
\hline \multicolumn{1}{|c|}{ Model } & $\boldsymbol{\beta}$ & T hitung & Sig \\
\hline Konstanta & 59,052 & 15,802 & 0,000 \\
Pertumbuhan Ekonomi & 1,657 & 2,720 & 0,019 \\
Pengangguran & 0,389 & 2,199 & 0,048 \\
\hline F hitung & \multicolumn{2}{|c|}{$\mathbf{4 , 9 6 5}$} & $\mathbf{0 , 0 2 7}$ \\
\hline
\end{tabular}

Sumber: Data Diolah, 2019.

Berdasarkan Tabel 4. Dapat diketahui bahwa secara parsial pertumbuhan ekonomi berpengaruh signifikan terhadap IPM. Hal ini dapat dilihat dari nilai signifikansinya $0,019<0,05$. Begitu pula dengan variabel pengangguran secara parsial berpengaruh signifikan terhadap IPM dengan nilai signifikansi $0,048<0,05$. Secara serentak Pertumbuhan Ekonomi dan Pengangguran berpengaruh signifikan terhadap IPM, hal ini dapat dilihat pada Tabel 4. Nilai signifikansinya sebesar $0,027<0,05$.

Berdasarkan analisis koefisien determinasi pada Tabel 2 diperoleh hasil bahwa kontribusi variabel independen terhadap variabel dependen sebesar 45,3\% dan sisanya $54,7 \%$ dipengaruhi oleh variabel lain seperti kemiskinan, tingkat pendidikan dan tingkat kesehatan. 


\section{Pembahasan}

Berdasarkan hasil analisis yang sudah dilakukan di Provinsi Sumatera Selatan pada periode tahun 2004-2018, tingkat pertumbuhan ekonomi memiliki pengaruh yang positif terhadap Indeks Pembangunan Manusia. Hal ini membuktikan bahwa ketika pertumbuhan ekonomi meningkat, maka produktivitas penduduk dalam memperoleh pendapatan akan meningkat. Sehingga akan meningkatkan proses pembangunan ekonomi dan dengan pertumbuhan ekonomi yang stabil akan menciptakan peningkatan terhadap Indeks Pembangunan Manusia.

Pengangguran juga berpengaruh positif terhadap Indeks Pembangunan Manusia di Provinsi Sumatera Selatan Periode Tahun 2004-2018. Hal ini bertantangan dengan teori yang seharusnya pengangguran memiliki pengaruh negative terhadap Indeks Pembangunan Manusia. Dimana apabila IPM meningkat maka mengakibatkan Pengangguran menurun. IPM Provinsi Sumatera selatan secara umum dari tahun 2004 sampai tahun 2018 memang nampaknya menurun namun dari Tahun 2014-2018 mulai berangsur meningkat. Apabila diamati lebih jauh ternyata pengaruh positif yang terjadi tersebut disebabkan keberadaan pengangguran friksional dimana semakin tinggi tingkat pendidikan seseorang maka seseorang cenderung untuk memilih-milih pekerjaan sehingga mereka lebih memilih menganggur dan mencoba mencari pekerjaan yang sesuai dengan tingkat pendidikannya. Pengangguran friksional tidak bisa dielakkan dari perekonomian yang sedang berubah. Hal ini sesuai dengan teori yang terkait dengan pengangguran friksional dimana yang dimaksud dengan pengangguran friksional adalah pengangguran yang terjadi disebabkan adanya kesulitan temporer dalam mempertemukan pencari kerja dan lowongan kerja yang ada. Penyebab terjadinya Kesulitan temporer ini terjadi disebabkan oleh beberapa faktor, antara lain ketersediaan lapangan kerja tidak sebanding dengan tenaga kerja yang mengakibatkan permintaan tenaga kerja berkurang. Selain itu penyebab lainnya dapat berbentuk sekedar waktu tunggu yang diperlukan selama prosedur pelamaran dan seleksi, atau terjadi karena faktor jarak atau kurangnya informasi (Mankiw, 2003).

\section{SIMPULAN}

Berdasarkan analisis dan pembahasan maka dapat disimpulkan bahwa:

1. Pertumbuhan ekonomi dan pengangguran berpengaruh terhadap Indeks Pembangunan Manusia (IPM) di Provinsi Sumatera Selatan Periode Tahun 20042018 baik secara parsial maupun simultan.

2. Pertumbuhan ekonomi yang meningkat akan menyebabkan produktivitas penduduk dalam memperoleh pendapatan akan meningkat. sehingga akan meningkatkan proses pembangunan ekonomi dan dengan pertumbuhan ekonomi yang stabil akan menciptakan peningkatan terhadap indeks pembangunan manusia.

3. Pengangguran friksional tidak bisa dielakkan dari perekonomian yang sedang berubah. Ketika permintaan terhadap barang bergeser maka permintaan terhadap tenaga kerja yang memproduksi barang-barang juga ikut bergeser. 


\section{DAFTAR PUSTAKA}

Adisasmita, Rahardjo (2015). Teori-Teori Pembangunan Ekonomi, Pertumbuhan Ekonomi dan Pertumbuhan wilayah, cetakan pertama. Yogyakarta : Penerbit Graha Ilmu.

Boediono (1999). Seri Sinopsis Pengantar Ilmu Ekonomi No. 4, Teori Pertumbuhan Ekonomi. Yogyakrta : BPFE.

Data Series Sumatera Selatan 2017.

https://ipm.bps.go.id. Diakses 8 Oktober 2019

Keadaan Ketenagakerjaan Provinsi Sumatera Selatan, Agustus 2018.

Kuncoro, Mudrajad (2004) Ekonomi Pembangunan: Teori, Masalah dan Kebijakan. Yogyakarta: UPP AMP YKPN.

Mankiw, N. Gregory (2003). Makro Ekonomi. Terjemahan: Fitria Liza, Imam Nurmawan. Jakarta: Penerbit Erlangga.

Provinsi Sumatera Selatan Dalam Angka 2004-2018.

Sukirno, Sadono (2013). Makro Ekonomi Modern, Perkembangan Pemikiran dari Klasik Hingga Keynesian Baru, Jakarta: PT Raja Grafindo Persada.

Todaro (2008). Pembangunan Ekonomi Di dunia Ketiga. Jakarta : Penerbit Erlangga.

UNDP (United Nations Development Programme), 1995. 